\title{
Challenges and Opportunities for Ecosystem-Based Management and Marine Spatial Planning in the Irish Sea
}

\author{
Tim O’Higgins, Linda O’Higgins, Anne Marie O’Hagan, \\ and Joseph Onwona Ansong
}

\section{Introduction}

The Ecosystem Approach to Management, synonymous with EcosystemBased Management (EBM), is "an approach which integrates the connections between land, air water and all living things including human beings and their institutions" (Mee et al. 2015). This approach is enshrined in both Directives of the European Union's (EU) Integrated Maritime Policy, the Marine Strategy Framework Directive (MSFD) and the Directive on Maritime Spatial Planning, and both mandate a regional approach. EBM fundamentally applies a place-based approach (Olesen et al. 2011; McLeod et al. 2005), where an ecosystem represents the place and effective ecosystem-based marine management and planning must incorporate spatial considerations to manage human uses at a scale that encompasses its impacts (Lackey 1998).

The theory of EBM is now at least 50 years old and builds on the early insights of Hardin (1968) in recognising the tragedy of the commons and the

T. O’Higgins $(\bowtie) \bullet$ L. O’Higgins $\bullet$ A. M. O’Hagan • J. O. Ansong MaREI Centre for Marine and Renewable Energy, Environmental Research Institute (ERI), University College Cork, Cork, Ireland e-mail: tim.ohiggins@ucc.ie 


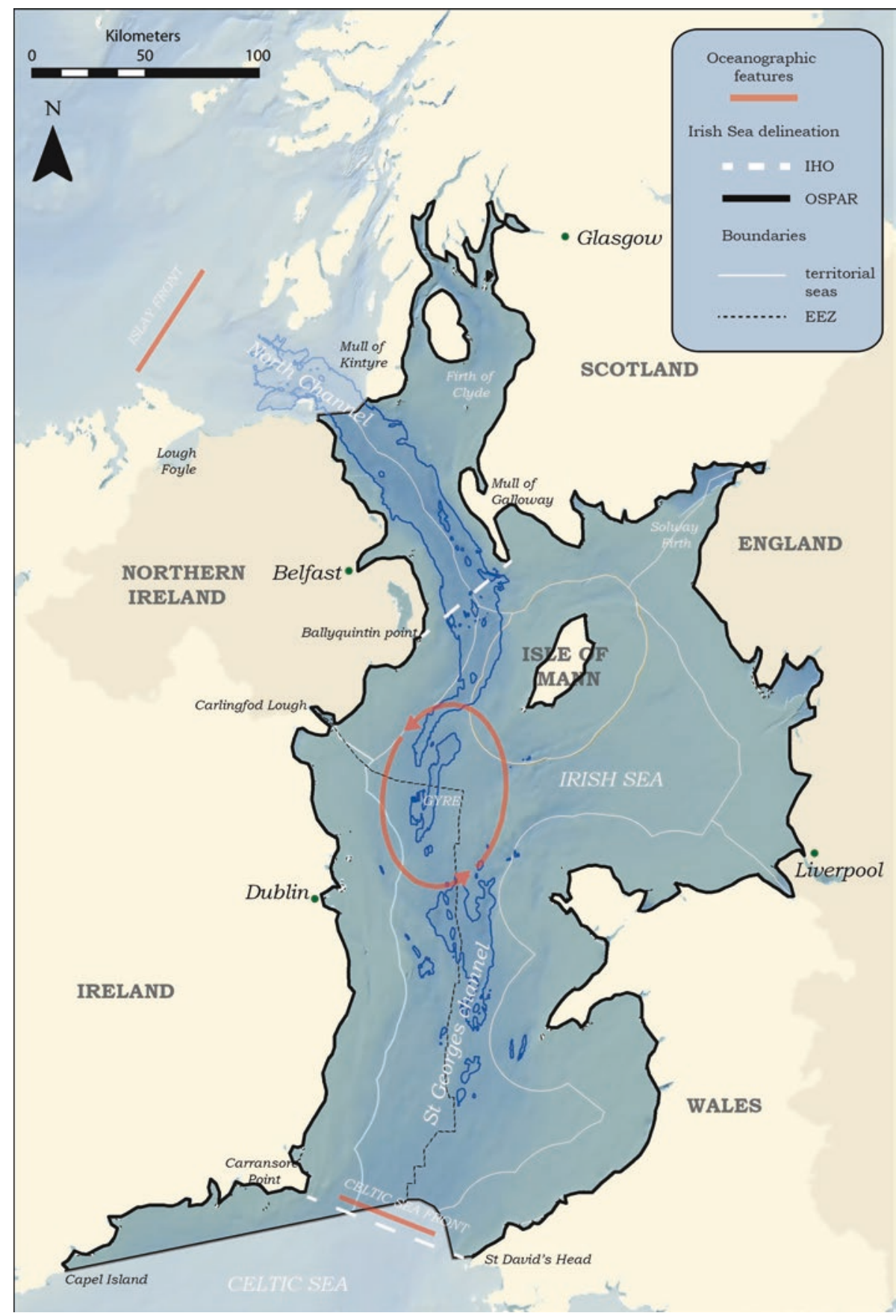

Fig. 3.1 Main geographic and oceanographic features of the Irish Sea. Data sources: Background bathymetry from http://www.emodnet-bathymetry.eu/. EEZ and territorial seas and boundaries from http://marineregions.org/. Location of oceanographic features re-drawn from information contained in Simpson 1974 and Simpson and Hunter 1976 
necessity to develop appropriate institutions for the management of common pool resources. Hardin's solution was the assignment of property rights to common pool resources. The problem of institutional fit has been the subject of intense enquiry (Folke et al. 2007), and empirical research has illustrated that there are many different types of management systems that can evolve or be applied to effectively manage common pool resources. While these systems may have some common properties, these tend to be context specific and there are no one-size-fits-all solutions (Dietz et al. 2003; Ostrom 2009). Successful management systems often occur where specific social conditions are present. These include a shared common understanding of the problems generated by poor management as well as shared norms of reciprocity and trust which build social capital (Ostrom 2003).

Another important element in the modern conception of the Ecosystem Approach is the inclusion of ecosystem services (MEA 2003; 2005; Tallis et al. 2010) and the recognition of multiple different types of values not all of which are readily amenable to economic valuation (O'Higgins 2017). The new EU Directive on Maritime Spatial Planning obliges all Member States to establish and implement maritime spatial plans with the aim:

to contribute to the sustainable development of energy sectors at sea, of maritime transport, and of the fisheries and aquaculture sectors, and to the preservation, protection and improvement of the environment, including resilience to climate change impacts. In addition, Member States may pursue other objectives such as the promotion of sustainable tourism and the sustainable extraction of raw materials. (Article 5(2))

However, the operationalisation of EBM in Marine/Maritime Spatial Planning (MSP) is not simple. Apart from the sea being dynamic and three dimensional, the major challenge is that the marine space remains a public good, remote from, but valued by, the public (Potts et al. 2016) and requires effective public representation in the processes of decision-making and trading off of multiple competing objectives. 
Box 3.1 The Bull Lagoon, Dublin Bay: An Historical, Social-Ecological Perspective

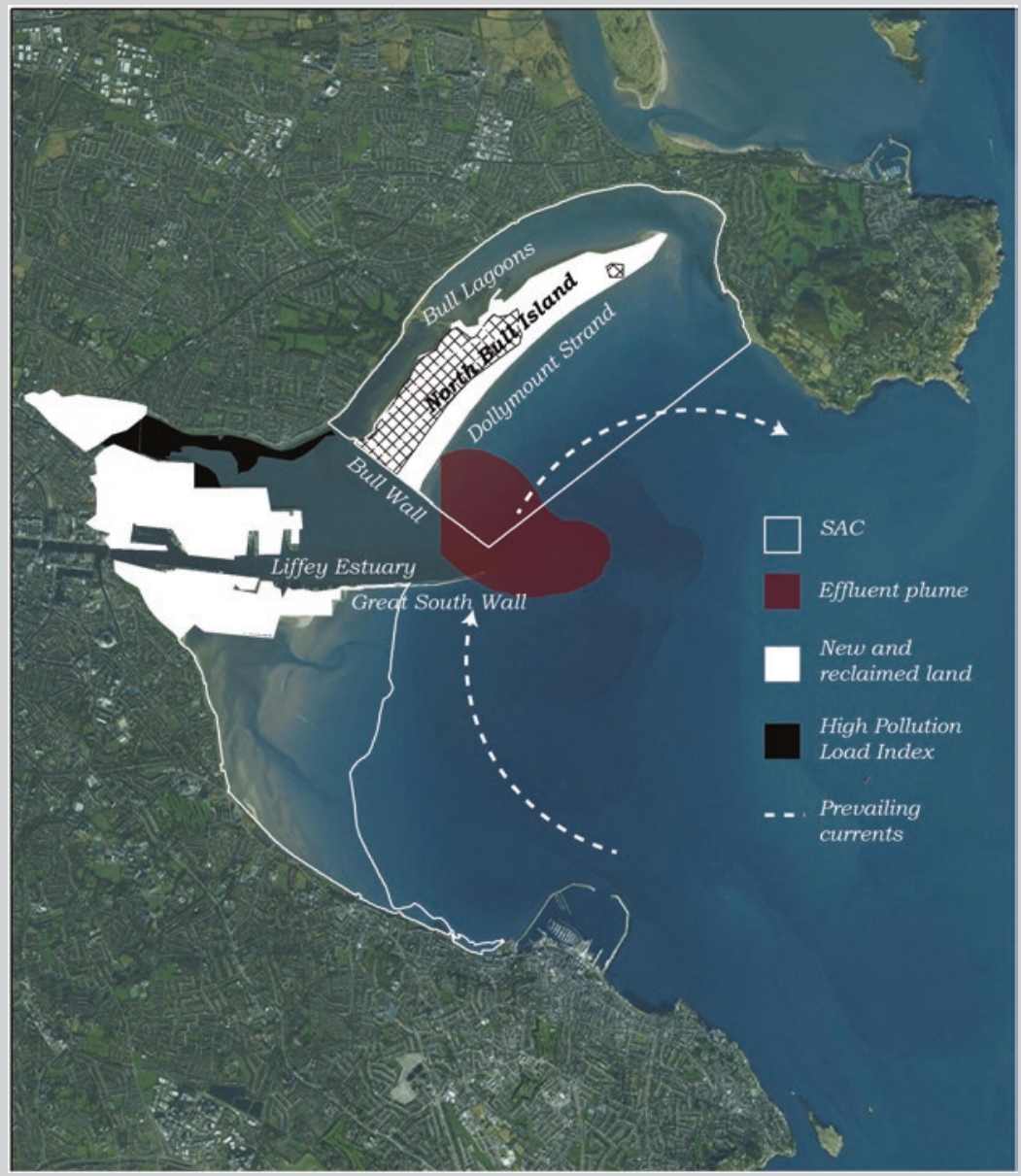

Fig. 3.2 Map of Dublin Bay showing human modification. The hatched area shows the extent of the Bull Island prior to 1913. Effluent data and Pollution Load Index from O'Higgins and Wilson (2005) and O'Higgins (2006)

At the turn of the eighteenth century, Dublin was a major and expanding trading port of the British Empire. Shipping activities in Dublin Port at the time were hampered by the presence of shifting shoals and sandbanks known as the North and South Bulls. The Ballast Board, established in 1786 to improve the Port of Dublin, oversaw the first major modification of Dublin Bay, the finalisation of the Great South Wall. At the same time, studies were initiated for construction of a wall on the northern bank of the River Liffey. The North or Bull Wall (first 
conceived by Captain William Bligh of "Mutiny on the Bounty" infamy) commenced construction and was completed by the early 1820 s. The wall was successful in improving the port, and the actions of the clockwise prevailing currents within Dublin Bay resulted in the gradual formation of a sandy spit, the North Bull Island. Over time the island grew and became a popular recreational location. On the landward side, the sedimentation of fine particulate matter from the cities' effluent (human and other) developed rich muddy sediments (the Bull Lagoons) supporting a diverse intertidal fauna, and avian fauna, annually attracting migrating flocks of Brent Geese. The Bull Island was designated a United Nations Educational, Scientific and Cultural Organization (UNESCO) biosphere reserve in 1981.

Today the North Bull Island is joined to the mainland by two causeways. Dollymount Strand, on the eastern side of the island, is a popular recreational area for walking, a designated bathing area and is popular for kite surfing. The island and lagoons also hold multiple environmental designations and is a Special Area of Conservation (SAC). As the city has grown, the same prevailing currents which resulted in the formation of the Bull Island have also carried (primary treated) sewage effluent from the Liffey mouth onto Dollymount Strand. A major capital investment in sewage treatment in 2003 brought secondary and tertiary treatment, but insufficient capacity has resulted in intermittent bathing water quality on Dollymount Strand, and efforts to maintain the Blue Flag status of the beach have faltered. In 2015, the whole of Dublin Bay was declared a UNESCO biosphere reserve.

The legacy of human modifications has resulted in an ecosystem in north Dublin Bay which is largely anthropogenic, suffers serious and persistent environmental problems, is highly valued for recreational use and is globally recognised in terms of natural heritage.

In the past decade, MSP has been used as a practical tool in applying EBM (Domingues-Tejo et al. 2016; Crowder and Norse 2008). The coupling of MSP and EBM has been seen as necessary and offers an approach for ensuring sustainable development where MSP defines high-level objectives and policies for spatial and temporal ordering of human activities (Ansong et al. 2017; Domingues-Tejo et al. 2016; Douvere 2008) by assessing the cumulative impacts of multiple human activities on the ecosystem at the appropriate scale (Stelzenmüller et al. 2018). Despite the mandate to adopt the Ecosystem Approach to management, this approach does not reflect the historic sectoral management practices around Europe, for example, in the application of the Common Fisheries Policy (CFP). Management options are constrained by legacy effects (O'Higgins et al. 2014), that is, historic and current drivers and pressures set the context in which future activities occur. At the European scale, there has been limited success in measurement or mapping of marine ecosystem services for marine environments, which is hampered by both the lack of data on economic values (Pendleton et al. 2007) and the lack of reliable 
information on the ecosystem processes associated with specific marine habitats (Maes et al. 2014). Developing the mechanisms and institutions to effectively manage shared marine areas at the regional scale is also a particular challenge (Van Tatenhove et al. 2014).

Some novel approaches are beginning to emerge with the potential for improving understanding of the dynamics of localised ecosystem service supply (Alexander et al. 2012; Potts et al. 2013) and novel approaches to understanding the trade-offs involved in MSP are gaining increasing popularity (Mayer et al. 2013). Here we examine the Irish Sea, taking a social-ecological systems approach to examine MSP. First the geographic and historical context of the Irish Sea is introduced, and the complexity of governance in the region is discussed. Next, the history of cooperation under the EU's environmental Directives is examined in the context of EBM. Major physical (oceanographic) features and the sectors that exploit them are discussed in the context of governance boundaries and institutional fit. Some examples of developing best practice in the Irish Sea which have emerged as part of the Supporting Implementation of Maritime Spatial Planning in the Celtic Seas (SIMCelt) project and other EU projects are identified and some promising avenues for developing a more holistic, ecosystem-based approach are identified. Finally, some potential future challenges for management of the Irish Sea are identified based on the emerging challenge of UK exit from the EU in March 2019.

\section{Irish Sea History, Geography and Politics}

There are several possible geographical definitions of the Irish Sea. Figure 3.1 illustrates the limits of the Irish Sea according to the International Hydrographic Organization (IHO), as well as those used for operational management purposes under the Oslo-Paris (OSPAR) Convention.

In terms of oceanography, this southern boundary also reflects a physical discontinuity, the Celtic Sea front (shown in red) (Simpson and Hunter 1974) where deeper stratified waters of the Celtic Sea meet the shallow tidally mixed waters of St. George's Channel (Simpson 1976). A second tidal front occurs to the north, between the Isle of Man and the island of Ireland, which defines the southern boundary of a gyre circulation system, which is characterised by stratification and associated with a fishery for Nephrops norvegicus (the Dublin Bay Prawn or Langoustine). Northwards, the next major physical discontinuity in water column characteristics occurs at the Islay front outside the formal bounds of the Irish Sea. 
Political boundaries within the Irish Sea are complex, to the west of the Irish Sea is the island of Ireland. Ireland is divided into two jurisdictions, the Republic of Ireland, comprised of 26 counties, and Northern Ireland, one of the devolved administrations of the UK, made up of six counties. To the east of the Irish Sea lies Britain, comprised of England (home of the central UK administration), Wales and Scotland (also UK devolved administrations). The Isle of Man, a UK protectorate, sits between Britain and Ireland. Under international law, the UK and Ireland as well as the Isle of Man claim territorial seas to $12 \mathrm{~nm}$ from the baseline and individual devolved administrations within the UK have responsibility for specified activities within their territorial sea. In addition, both the UK and Ireland have claimed Exclusive Economic Zones beyond their territorial sea, small portions of which occur within the Irish Sea (Fig. 3.1 dashed line) though formal maritime boundaries in the border bays of Carlingford Lough and Lough Foyle have never been agreed on.

Historically all the administrations bordering the Irish Sea were under British jurisdiction, and the areas' main cities share this common history of development. Several major cities are located on the shores of the Irish Sea including Glasgow (pop. 0.6m) and Belfast (pop 1.2m) to the north, both major historical ship building centres as well as Dublin (pop. $1.3 \mathrm{~m}$ ), which was once considered the second city of the British Empire, and Liverpool (pop. $1.38 \mathrm{~m}$ ), its major trading port. The free movement of people between Ireland and the UK remains a legacy of this shared history. The example of Dublin Bay (Box 3.1) illustrates how the legacy of a large-scale geopolitical process, the expansion of the British Empire, has affected the supply and demand for the production of ecosystem services (recreational and cultural benefits) over long timescales resulting in a distinct and highly valued, nested social-ecological system embedded within the physical and social context of the larger Irish Sea.

\section{The EU as a Driving Force for Environmental Efforts}

Apart from international law such as the United Nations Convention on the Law of the Sea (UNCLOS), the Convention on Biological Diversity, the Aarhus Convention, and the Espoo Convention, a common basis for cooperation between Ireland and the UK (including its devolved administrations) in addressing environmental conflicts and the management of activities occurring in, or impacting upon, the Irish Sea has occurred as the result of 
membership of the EU (and its precursors). Both the UK and Ireland joined in 1973 and are subject to EU law, much of which mandates regional cooperation. As EU Member States, both sovereign countries have been subject to the provisions of the CFP for the last 40 years, under its common legal basis.

The Birds Directive (EEC, 1979 as amended 2009) established the basis for international cooperation on the management of wild birds and was subsequently complemented by the Habitats Directive (EEC 1992), which together provide for the protection of rare and threatened species and natural habitat types through the Natura 2000 network. The European Court of Justice confirmed in 2004 that the provisions of the Habitats Directive extend to the limit of the Exclusive Economic Zone (200 nautical miles) and Member States must designate SACs and Special Protection Areas to protect listed habitats and species.

The adoption of the Water Framework Directive (WFD) (EC, 2000) obliges Member States to meet Good Ecological Status (GES) in transitional (estuarine) and coastal waters and provides a mandate for regional cooperation. It was the first piece of EU legislation to introduce management of river basins and adjacent coastal waters at the catchment scale, through the establishment of River Basin Districts (RBDs). The WFD requires transboundary cooperation for international RBDs. The introduction of the MSFD (EC, 2008) considerably expanded the legal basis for regional cooperation with respect to the marine environment. The Directive mandates that Member States use EBM to achieve Good Environmental Status (GEnS) on a regional basis and contains 11 descriptors to assist Member States in interpreting what GEnS should look like in practice. The descriptors include commercial fisheries, biodiversity and eutrophication which are already regulated by the EU's CFP, Habitats Directive and the WFD, respectively and a suite of relatively new descriptors including marine litter and the introduction of energy (including underwater noise). The Maritime Spatial Planning Directive (2014/85/EU) (EC 2014a) complements the transboundary approach of the MSFD by ensuring that there is a sustainable balance between Member State economic ambitions and the achievement of GEnS.

While these Directives have provided a common framework for environmental protection in the marine environment, engagement with, and implementation of, the Directives have varied between the devolved authorities in the UK and also between the UK and Ireland. Generally speaking, the UK has traditionally engaged more proactively with environmental legislation and implemented more stringent measures than strictly necessary, sometimes referred to as "gold plating", while in the Republic of Ireland transposition and implementation have sometimes been more reactive, in response to 
infraction proceedings or the potential for these. By contrast, the Scottish Government has pursued a very proactive approach towards MSP and in the development of the Spatial Data Infrastructure, and Scotland is seen to be leading the way in the MSP process. The Scottish Marine Plan Interactive, their national digital atlas, contains a shapefile of a Scottish Exclusive Economic Zone, perhaps belying the ambition for independence of the governing Scottish National Party, which may to some extent explain their proactive approach towards EU policy and its implementation.

Under the first implementation cycle of the MSFD, the European Commission recognised a number of serious challenges to implementation at regional scales (EC 2014b). Most recently, the revised Commission Decision on Descriptors (EC 2017) sets out more rigorous definitions of GEnS criteria, meaning that the second cycle of implementation is likely to be more demanding in terms of implementation. The regional cooperation and mandate for more participatory "bottom-up" approaches under the MSFD and MSP Directives have resulted in several efforts to develop regional and sub-regional fora for marine environmental management. There have been a number of European research projects including the Partnerships Involving Stakeholders in the Celtic Sea Ecosystem (PISCES), Celtic Seas Partnership and Transboundary Planning in the European Atlantic (TPEA) projects (with the aim of harmonising regional cooperation and developing Ecosystem Approaches) to management in the region (see Chap. 6 in this volume). However, as with the WFD, the timescales for national implementation of the MSFD have resulted in limited harmonisation of approaches at the regional level. Supported by EU research funding, project-based efforts have each brought together various stakeholders to encourage multisectoral perspectives for incorporation into regional management. However, while these projects have provided a platform for consideration of different perspectives in developing management plans, they have no legal standing, are time-limited, and while it may be politically expedient for national governments to engage with such groups, there is no legal requirement to follow up on any specific recommendations. The same can be said for non-statutory national initiatives, mainly those advanced by the UK government to support regional EBM and MSP at the Irish Sea scale such as the Irish Sea Pilot project (2002-2004) and the Marine Spatial Planning Pilot (2004-2006). While these projects engaged government officials from the Republic of Ireland, the Isle of Man, the devolved administrations of the UK and many Irish Sea stakeholders and supported the statutory institutionalisation of MSP in the UK, they did not result in a more formal or statutory approach to partnership between the UK and Ireland. Transboundary working and partnership at the Irish Sea scale has 
mainly been at the strategic level of sharing information (Kidd and McGowan 2013) while operational cooperation has been very limited, though cooperation is a legal requirement under Article 11 of the MSP Directive.

Outside of the EU framework the only institution with an established legal basis for cooperation on matters relating to the marine environment of the North-East Atlantic, including the Irish Sea, is the OSPAR Commission created under the OSPAR Convention for the Protection of the Marine Environment of the North-East Atlantic. The Convention objectives are taken forward through the adoption of decisions which are legally binding on the Contracting Parties, and as such it represents a forum for regional cooperation, and beyond which it may become increasingly important as the UK plans to exit the EU. OSPAR objectives and approaches are very much in line with those of the EU and OSPAR structures have been used as a forum to generate a common basis for cooperation for the WFD, the Habitats Directive and, more recently, and with relative success compared to other regional seas (EC 2014b), for the MSFD. Many of the transitional waters on both sides of the Irish Sea are considered to be OSPAR problem areas or OSPAR potential problem areas in terms of eutrophication (OSPAR 2008). OSPAR offers the potential for continued regional cooperation in tackling eutrophication beyond the proposed UK exit in March 2019.

\subsection{Managing Multiple Sectors}

Much of the maritime activity in the Irish Sea has developed independently from the relatively new concepts of EBM and MSP and has been influenced only marginally by environmental legislation or formal MSP process. Maritime transport is the principal and traditional economic activity making use of marine spaces. In the Republic of Ireland, maritime transport accounts for $85 \%$ of the total volume of goods and $56 \%$ of the total value of goods traded nationally (Vega and Hynes 2017). In 2015, 27 million tonnes, 55\% of the total volume of goods received or forwarded by ship in Ireland passed through the Irish Sea, including $84 \%$ of goods traded by sea with the UK. For the UK, this volume makes up a much smaller, but nevertheless significant, proportion of total maritime trade (approximately 10\%). ${ }^{1}$ Figure 3.3 shows the relative density of shipping and Automatic Identification System (AIS) ship track data for the passenger/roll-on roll-off vessels in the Irish Sea.

\footnotetext{
${ }^{1}$ Total UK maritime Freight for 2015 was 182,535,000 tonnes (Dept. of Transport Statistics, 2016).
} 


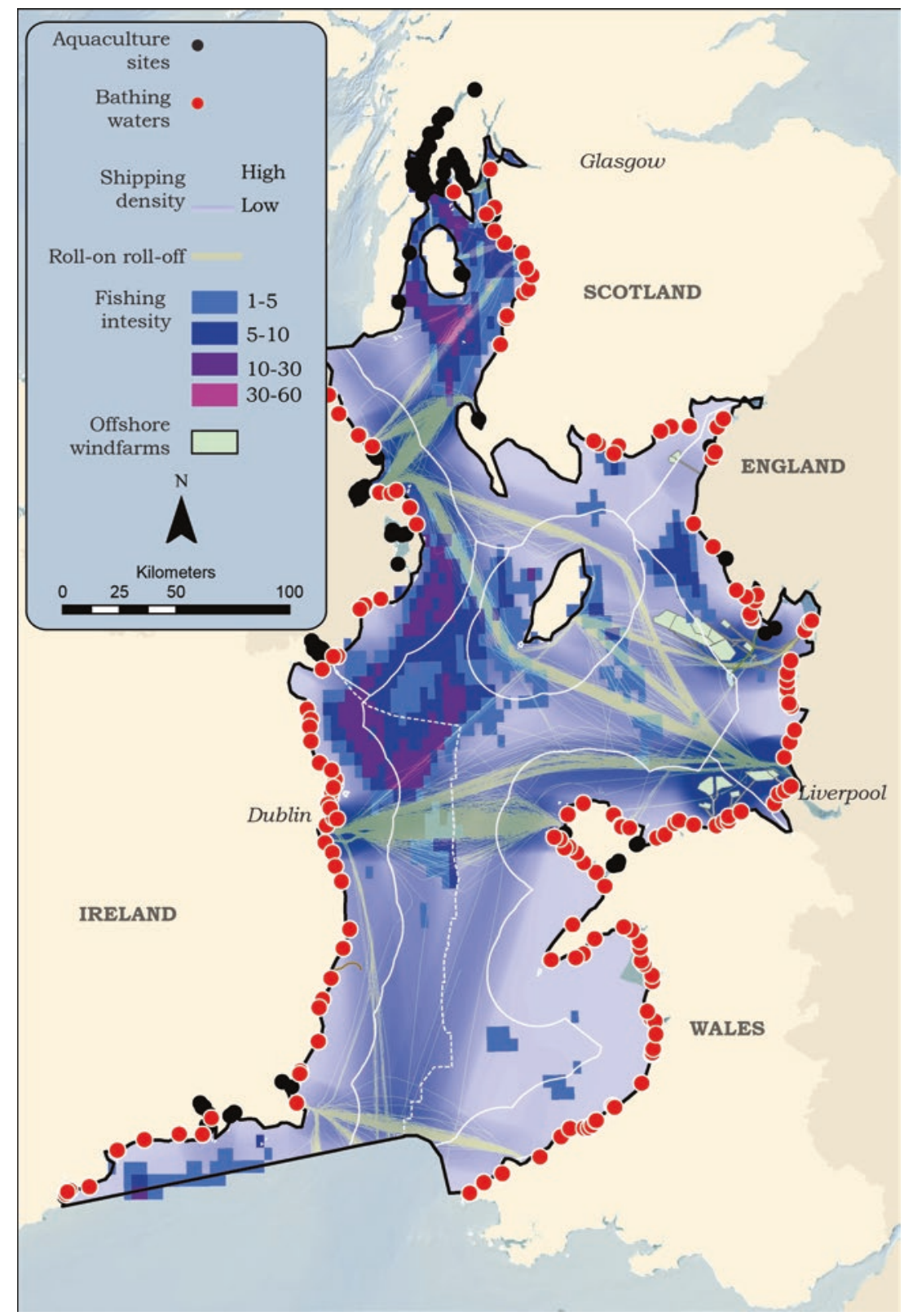

Fig. 3.3 Map of sectors explicitly addressed in the MSP Directive. Fishing pressure is expressed as swept area ratio. Renewable energy is shown in pale green. Main roll-on roll-off shipping routes are shown in yellow. Fishing pressure is shown in blue to purple. Designated bathing waters are shown in red. Aquaculture sites are shown as black circles. Data sources: Background bathymetry from http://www.emodnet-bathymetry. eu/. Aquaculture sites-https://atlas.marine.ie/\#?c=53.9043:-15.8972:6. Shipping density and roll-on roll-off are based on data from https://data.gov.uk/. Fishing Intensity: OSPAR, https://odims.ospar.org/. Offshore wind farms: http://www.emodnet-humanactivities.eu/search-results. php?dataname=Wind+Farms+\%28Polygons\%29 
The second major long-standing sector currently operating within the Irish Sea is that of fishing. The most lucrative fishery in the Irish Sea is that for Nephrops norvegicus (the Dublin Bay Prawn or Langoustine), though relatively minor fisheries for herring, plaice, haddock, whiting and sole also exist. The most productive and lucrative area for the fishery lies within the gyre of the western Irish Sea (ICES region VIIa, Unit 15) and straddles the limits of the territorial seas of Ireland, Northern Ireland and the Isle of Man as well as the UK and Irish EEZs and the Isle of Man (Fig. 3.4). The catch from the area is worth approximately $€ 54$ million annually (ICES 2016), but fishing is more intense in the territorial waters of the Republic of Ireland (Fig. 3.4), while the majority of the quota (75\%) is landed in Northern Ireland (ICES 2016). Quotas for this and other fisheries in the Irish Sea are currently managed under the CFP. If no new fishing arrangements are made prior to the UK exit from the EU, Northern Irish fishers may no longer have access to the more valuable Nephrops grounds in the territorial waters of the Republic and could stand to lose out economically in this location. There is also a clear requirement for continued regional cooperation if this and other shared stocks are to be harvested sustainably.

Aquaculture is also specifically referred to in the MSP Directive, though it has a patchy distribution in the Irish Sea. Scotland is a leading global aquaculture producer focusing on farmed salmon (with total annual finfish production in 2014 of $€ 855.6$ million) with a smaller national shellfisheries sector (€13.1 million). Within the study area, there are several Scottish companies cultivating salmon as well as oysters within the fordic loch systems. Marine aquaculture in the Irish Sea for Wales, Northern Ireland and the Republic of Ireland is confined to shellfish, principally mussels, but also oysters with annual production of shellfish values at $€ 18.7$ million, $€ 5.9$ million $^{2}$ and $€ 8.5$ million (Hambrey and Evans 2016; BIM 2014). A similar situation occurs in Ireland and Northern Ireland where production also focuses on mussels as well as oysters. The locations of aquaculture sites in the Irish Sea are shown in Fig. 3.4. Throughout the Irish Sea, aquaculture sites are currently confined to inshore sites, generally within sheltered bays and inlets, but offshore expansion of the industry has the potential to cause increased spatial conflict with other activities.

Both the UK and Ireland have ambitious targets for the development of offshore energy in the Irish Sea. Wind farms in the Irish Sea alone have an installed capacity of over 2 GW (ABPmer 2016) and account for about 2.6\%

${ }^{2} \mathrm{NI}$ production values also include Lough Foyle outside the Irish Sea. 
(a)

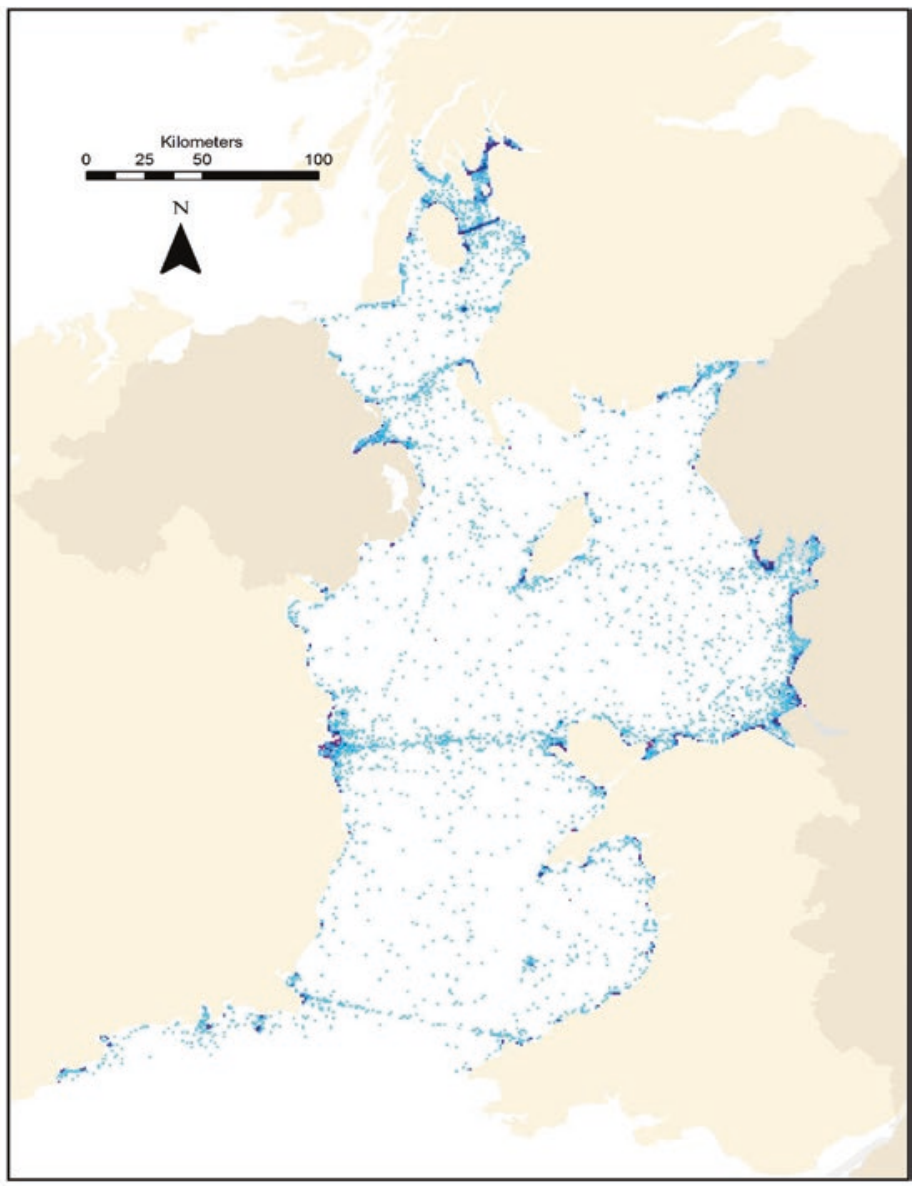

(b)

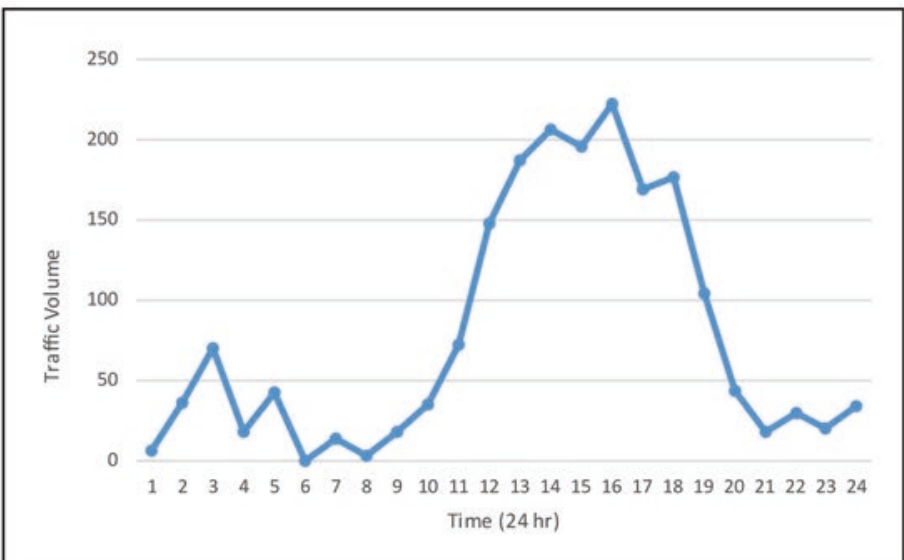

Fig. 3.4 Examples of crowd-sourced and open data. (a) Photography User Days based on the InVEST model (Adamowicz et al. 2011). (b) Data from Dublin's traffic monitoring system showing temporal patterns in beach use for Dollymount Strand. Data source: https://data.gov.ie/dataset/volume-data-for-dublin-city-from-dublin-city-council-traffic-departments-scats-system 
of consented offshore wind in Europe. ${ }^{3}$ Development of offshore wind in the Republic of Ireland commenced in 2003 with the construction of the Arklow Bank array (Risø National Laboratory 2004), but subsequent development has stalled. The majority of the wind farms in the Irish Sea (ten wind farms sites) have been developed in the English and Scottish territorial waters of the eastern Irish Sea (Fig. 3.3). Though the major development of offshore energy envisaged under national and EU policies has not yet come to fruition, other offshore renewable energy projects are at different stages of development. There are, for example, two major tidal developments in Northern Ireland waters at an advanced planning stage (Fair Head Tidal and Tidal Ventures, both $100 \mathrm{MW}$ projects).

\subsection{Management Challenges}

The spatial characteristics of specific sectoral activities operating within the Irish Sea have implications for their management. Both offshore energy and aquaculture are relatively static, occurring at fixed sites and within specific jurisdictions and consequently both operational monitoring and overarching regulation of these activities occurs at national level through the responsible or devolved authority, where applicable. As a result, data on the location of particular activities, for example, are held by different institutions with different data policies, procedures and requirements, and there is no centralised repository of spatial data for all aquaculture sites or renewable energy sites in the Irish Sea. Most data available are based on the static boundaries of national jurisdictions. For non-mobile activities, this situation may be sufficient to enable local management. It may, however, be considered an obstacle from the perspective of more holistic regional EBM. For example, development of offshore energy farms has the potential to reduce visual amenity across international boundaries and potentially resulting in conflicts.

For mobile sectors operating within the area, for example, maritime transport and fisheries, the lack of a centralised resource for the collection and analysis of spatial information is perhaps more of a problem. The AIS system used to monitor vessels over the length of $15 \mathrm{~m}$ generate high volumes of almost continuous spatial information as do the Vessel Monitoring Systems (VMS) used for the monitoring of fishing effort. The patterns contained within this data are of vital importance not just for maritime safety but also in

\footnotetext{
${ }^{3} \mathrm{https}$ //windeurope.org/wp-content/uploads/files/about-wind/statistics/WindEurope-AnnualOffshore-Statistics-2016.pdf.
} 
the assessment of the levels of activity within the Irish Sea ecosystem and the impacts on the environment. While there have been centralised efforts (under the auspices of the International Council for the Exploration of the Seas) to make VMS data available for analysis, national approaches to integration and compilation of data have differed, resulting in duplication of efforts and inability to cross-compare nationally analysed data. For AIS, the sheer volume and the distributed nature of the data have meant that there has been little coordinated effort in data synthesis at the scale of the Irish Sea.

While information overload is the problem for some sectors, for other activities, a lack of information hampers local and regional ability to make informed choices. The latter is particularly true for recreational activities. For example, there are 160 designated bathing waters in the Irish Sea, which undergo regular water quality monitoring, but for those waters, there is more accurate information on the number of faecal coliforms in the water column than on the number of users of the bathing waters, and still less is known about how recreational use changes with variations in water quality. The MSP Directive also makes provision for incorporating the objectives of sustainable tourism development in spatial plans. As with bathing water quality, the relationships between tourism and environmental quality are poorly understood. While regional tourism statistics do exist, these are difficult to relate directly to specific environmental features, and recreational activities which utilise ecosystem services are often not part of the market economy, therefore estimating their value and consequently weighting them against other activities with well-constrained spatial scales and known market values remains a major challenge. While the paucity of appropriate ecosystem services data to support decision-making is not confined to the Irish Sea, the complexity of the governance structures including two nations, three devolved authorities and one Crown protectorate, each with their own unique economic and social conditions and national priorities, can result in additional complexity in terms of sourcing, harmonising and centralising data.

\section{Good Practices: The Solway Firth Partnership}

Despite the complexity of governance and the data challenges identified above, there are a number of emerging initiatives and technologies that offer the potential to assist MSP at the regional scale. 
Integrated management and planning of marine resources across borders offers an approach to ensure that shared resources and ecosystem units are effectively managed. However, differences in timelines for the implementation of MSFD and MSP pose challenges to the management and planning of shared local and communal resources. One of the initiatives in Britain fostering formal cross-border working and local input into decision-making is the use of coastal and marine partnerships. One such partnership is the Solway Firth (SWF) Partnership.

The SWF is a unique ecosystem which lies between England and Scotland (Fig. 3.1) and is home to various national and international conservation sites (Ramsar site, Special Protection Area and SAC), historical and archaeological sites. It also hosts the largest offshore wind farm in Scottish waters (Robin Rigg). Although this ecosystem is managed and regulated primarily under two pieces of legislation (the UK Marine and Coastal Access Act (MCAA) 2009 for the English side and the Marine (Scotland) Act 2010 for the Scottish), there is policy convergence under the UK Marine Policy Statement (HM Government 2011). This policy statement derives from Section 44 of the MCAA, whereby a joint policy statement outlines the general policies of the four respective administrations that contribute to the achievement of sustainable development of the UK's marine area. Approaches being applied in the SWF to ensure joint initiatives include:

- coordination of data sharing facilitated by Scotland's National Marine Plan interactive (webGIS) \& the UK Marine Science Co-ordination Committee research platform;

- harmonisation of public budget and funding available on each side of the border from local Councils and state agencies. The SWF Partnership has developed a common business plan for the SWF;

- coordination of SWF Regional Plan with Scotland National MSP;

- coordination of SWF Regional Plan with Scottish sectoral marine plans for offshore wind, wave and tidal energy; and

- joined up stakeholder involvement in the MSP process.

Through the SIMCelt project, practical approaches for planning across borders in the SWF were explored by increasing awareness of transboundary issues, highlighting conflicts in cross-border planning and management, enhancing integration and cooperation between the devolved authorities. Such lessons, joint initiatives, policies and funding will be relevant across the whole Irish Sea, especially on the island of Ireland to foster cooperation and integration to ensure effective EBM. 
While hard, geographic data are often available for specific sectors, for example, the maps of fishing (a provisioning ecosystem services) shown in Fig. 3.2, finding appropriate data for the incorporation of cultural ecosystem services and recreational values into marine planning at appropriate scales remains a challenge. The potential for new sources of data to inform spatial planning is beginning to emerge. Figure 3.4a shows the levels of recreational photography within the Irish Sea area, based on the number of Photography User Days, and was calculated using InVEST data modelling suite (see Adamowicz et al. 2011 for detail). While patterns of photography are clearly linked to patterns of travel (photographs are clustered around the main ferry routes), some clusters of photographs found offshore do not match up with expected travel patterns and may indicate the existence of features of particular importance in terms of recreational and cultural values. Figure $3.4 \mathrm{~b}$ shows temporal patterns in recreational beach use in Bull Island Dublin (see Box 3.1) inferred from traffic data on the "Dublin Bay Dashboard" developed as part of Celtic Seas Partnership Project illustrating how existing public data can be used to gather information on recreational use patterns.

With the increasing amount of spatial and temporal information being generated from the bottom-up by members of the public and local government initiatives (Dublin's traffic monitoring system), developing appropriate techniques for gathering and analysing such "big data" provides a promising avenue for incorporating semi-quantitative ecosystem services data into spatial planning, which may help to better represent data on public values into management of the public good that are the seas.

\section{$5 \quad$ Future Management}

The EU has provided the legislative framework and common basis for cooperation on maritime affairs and marine environmental management and protection over the last 40 years. Though concerted regional efforts have been sporadic and project-based, nevertheless these efforts have helped to develop an international community of best practice and expertise in marine planning and environmental management in the UK and Ireland. With the UK decision to exit from the EU, the future basis for cooperation is less certain.

One high-profile issue in the referendum campaign was the CFP, and it is highly likely that the UK will now enforce a more restrictive regime on international vessels fishing within its national waters. Such a change has clear implications for the management of the Nephrops fishery in the Irish Sea. 
There is no clear basis for common future exploitation of this shared resource in this area where boundaries are still contested.

At present, the split of Nephrops fisheries quotas is made centrally at the EU level; in the absence of this, an alternative process will be needed to allocate and enforce quotas. In the absence of a local cross-border management arrangement, it is entirely possible that the fishery might return to an openaccess regime with its inherent tendencies towards the tragedy of the commons. Alternatively, restricting access to the fishery for non-national vessels could potentially revive historic tensions between north and south.

The examples of successful local regional cooperation in the Solway Firth, explored as part of the SIMCelt project, may provide a model for local management of the resource on a transboundary (Irish all island) cooperation basis, in keeping with the concepts of an Ecosystem Approach. However, such cooperation would necessitate the development of appropriate local crossborder institutions. The Loughs Agency, as one of the North-South Implementation bodies under the Good Friday Agreement, provides such a role, but has a remit only to manage fisheries and aquaculture. More effective management would require an institution with a wider remit.

While fisheries represent a high-profile and contentious example of potential future conflicts, maritime transport in the Irish Sea is particularly vital to Ireland and not insignificant to the UK. Under any planning framework (whether inside or outside of the EU), efficient transport is likely to be of the highest priorities when considering maritime development. There is a tradition of free trade and transport across the Irish Sea, driven by markets and their inherent efficiencies, which is centuries old and, at least in terms of its spatial patterns, is unlikely to be affected by changes in obligations for environmental protection or for MSP. The legacy of historic shipping and its infrastructure will continue to shape the patterns of transport in the Irish Sea (just as they have shaped the social and ecological development of the Dublin Bay social-ecological system). Nevertheless, depending on the nature of future EU-UK trade, customs and tariffs arrangements, volumes of ship traffic could potentially stand to change, potentially favouring more direct routes between Ireland and continental Europe.

In terms of marine renewable energy development, given the short distances between countries, and across the Irish Sea, in the absence of a harmonised approach to marine planning, unilateral decisions of individual nations (or of devolved authorities on certain matters) within their own territorial waters risk imposing externalities, dis-benefits in terms of cultural and amenity values (cultural ecosystem services) on the coastlines of other countries. The two states bordering the Irish Sea have had an uneasy relationship 
in the past and, if planning conflicts are to be avoided, some means of operational cross-border cooperation will need to be maintained. OSPAR may continue to provide a mechanism for such cooperation.

Overall, the activities currently occurring within the Irish Sea are strongly influenced by their history of development. As illustrated by the case of Dublin Bay, nested sub-systems of human uses, both commercial and recreational, have evolved over time and are influenced by global trade, transport and economy as well as local patterns of physical and social phenomena. The challenges and the potential for regional MSP in terms of governance, harmonisation of information and joined approaches are beginning to emerge, yet given the unknown nature of the new relationship developing between the UK and the EU, the future of the MSP process within the Irish Sea is highly uncertain. The impact of the MSP Directive on the activities occurring within the Irish Sea and the patterns of resource use and exploitation have yet to be experienced. Whatever the future political context following the UK departure from the EU, effective sustainable management for the Irish Sea will require ecosystem-based approaches, which reflect the complexity of the Irish Sea and its nested social and ecological sub-systems and involve transboundary cooperation. Whether the political and economic conditions will favour such approaches will be critical in determining the outlook for the Irish Sea environment and the ecosystem services it provides to the people on its shores.

Acknowledgements This material is based upon works supported by Science Foundation Ireland (SFI) under Marine and Renewable Energy Ireland (MaREI) Centre (12/RC/2302). The Open Access fee of this chapter was provided from the same source.

\section{References}

ABPmer. (2016). Future Trends in the Celtic Seas: Summary Report. ABPmer Report No. R.2584a. A Report Produced by ABPmer and ICF International for the Celtic Seas Partnership, August.

Adamowicz, W. L., Naidoo, R., Nelson, E., Polasky, S., \& Zhang, J. (2011). NatureBased Tourism and Recreation. In P. Kareiva, G. Daily, T. Ricketts, H. Tallis, \& S. Polasky (Eds.), Natural Capital: Theory and Practice of Mapping Ecosystem Services. New York: Oxford University Press.

Alexander, K., Janssen, R., Arciniegas, G., O'Higgins, T., Eikelboom, T., \& Wilding, T. (2012). Interactive Marine Spatial Planning: Siting Tidal Energy Arrays Around the Mull of Kintyre. PloS One. https://doi.org/10.1371/journal.pone.0030031 
Ansong, J., Gissi, E., \& Calado, H. (2017). An Approach to Ecosystem-Based Management in Maritime Spatial Planning Process. Ocean and Coastal Management, 141, 65-81.

BIM. (2014). BIM Annual Aquaculture Survey. 16 pp. http://www.bim.ie/media/ $\mathrm{bim} /$ content/publications/BIM,Aquaculture,Survey,2014.pdf. accessed 7/9/18

Crowder, L., \& Norse, E. (2008). Essential Ecological Insights for Marine EcosystemBased Management and Marine Spatial Planning. Marine Policy, 32, 772-778.

Dietz, T., Ostrom, E., \& Stern, C. (2003). The Struggle to Manage the Commons. Science, 302, 1907-1912.

Domingues-Tejo, E., Metternicht, E., Johnston, E., \& Hedge, L. (2016). Marine Spatial Planning Advancing the Ecosystem-Based Approach to Coastal Zone Management: A Review. Marine Policy, 72, 115-130.

Douvere, F. (2008). The Importance of Marine Spatial Planning in Advancing Ecosystem-Based Sea Use Management. Marine Policy, 32, 762-771.

EC. (2014a). Directive 2014/89/EU of the European Parliament and of the Council of 23rd of July 2014 Establishing a Framework for Maritime Spatial Planning. Official Journal of the European Union. L257/135.

EC. (2014b). Report from the Commission to the Council and the European Parliament on the First Phase of Implementation of the Marine Strategy Framework Directive (2008/56/EC). COM (2014) 97 final.

EC. (2017). Commission Decision (EU) 2017/848 of 17 May 2017 Laying Down Criteria and Methodological Standards on Good Environmental Status of Marine Waters and Specifications and Standardized Methods for Monitoring and Assessment, and Repealing Decision 2010/477/EU.

EC. (2000). Directive 2000/60/EC of the European Parliament and of the Council of 23 October 2000 Establishing a Framework for Community Actions in the Field of Water Policy. Official Journal of the European Communities. 2000; L327, 1.22.12.2000.

EC. (2008). Directive 2008/56/EC of the European Parliament and of the Council of 17 June 2008 Establishing a Framework for Community Action in the Field of Marine Environmental Policy. Official Journal of the European Union. 2008.2 L $164 / 19$.

EC Directive 2009/147/EC of the European Parliament and of the Council of 30 November 2009 on the Conservation of Wild Birds (Codified Version). Official Journal of the European Union. 2009; L20/7.

EEC. (1979). Council Directive 79/409/EEC of 2 April 1979 on the Conservation of Wild Birds. Official Journal of the EEC. 1979 C24.

EEC. (1992). Council Directive 92/43/EEC of 21 May 1992 on the Conservation of Natural Habitats and of Wild Fauna and Flora. Official Journal of the EEC. 1992; L206/7.

Folke, C., Pritchard, L., Berkes, F., Colding, J., \& Svedin, U. (2007). The Problem of Fit Between Ecosystems and Institutions: Ten Years Later. Ecology and Society, 12(1), 30 Retrieved from http://www.ecologyandsociety.org/vol12/iss1/art30/. 
Hambrey, J., \& Evans, S. (2016). SR694. Aquaculture in England, Wales and Northern Ireland (p. 162). Seafish.

Hardin, G. (1968). The Tragedy of the Commons. Science, 162, 1243-1248.

HM Government. Marine and Coastal Access Act 2009. Retrieved from http://www. legislation.gov.uk/ukpga/2009/23/contents.

HM Government. (2011). UK Marine Policy Statement. HMSO ISBN 978010 8510434. Retrieved from http://www.official-documents.

ICES. (2016). ICES Advice on Fishing Opportunities Catch and Effort in the Celtic Seas Ecoregion. ICES Copenhagen.

Kidd, S., \& McGowan, L. (2013). Constructing a Ladder of Transnational Partnership Working in Support of Marine Spatial Planning: Thoughts from the Irish Sea. Journal of Environmental Management, 126, 63-71.

Lackey, R. T. (1998). Seven Pillars of Ecosystem Management. Landscape and Urban Planning, 40(1-3), 21-30.

Maes, J., Teller, A., Erhard, M., et al. (2014). Mapping and Assessment of Ecosystem and Their Services. Indicators for Ecosystem Assessments Under Action 5 of the EU Biodiversity Strategy to 2020. Luxembourg: Publications Office of the European Union. ISBN 978-92-79-36161-6.

Mayer, I., Zhou, Q., Lo, J., Abspoel, L., Keijser, X., Olsen, E., Nixon, E., \& Kannen, A. (2013). Integrated, Ecosystem-Based Marine Spatial Planning: Design and Results of a Game-Based, Quasi-Experiment. Ocean and Coastal Management, 82, 7-26.

McLeod, K. L., Lubchenco, J., Palumbi, S. R., \& Rosenberg, A. A. (2005). Scientific Consensus Statement on Marine Ecosystem-Based Management. Prepared by Scientists and Policy Experts to Provide Information About Coasts and Oceans to U.S. Policy-Makers. Retrieved from http://www.compassonline.org/sites/all/files/ document_files/EBM_Consensus_Statement_v12.pdf.

MEA. (2003). Ecosystems and Human Well-Being: A Framework for Assessment. Washington, DC: Island Press.

MEA. (2005). Ecosystems and Human Well-Being: Current State and Trends: Findings of the Condition and Trends Working Group. Retrieved from http:// www.unep.org/.

Mee, L. D., Cooper, P. C., Gilbert, A. J., Kannen, A., \& O’Higgins, T. (2015). Sustaining Europe's Seas as Coupled Social-Ecological Systems. Ecology and Society, 19(3). Retrieved from https://doi.org/10.5751/ES-07143-200101.

O'Higgins, T. (2006). Dublin Bay Water Quality Monitoring Programme Biological Monitoring Report (p. 57). Dublin City Council.

O'Higgins, T. G. (2017). You Can't Eat Biodiversity: Agency and Irrational Norms in European Aquatic Environmental Policy. Challenges in Sustainability, 5(1), 43-51. O'Higgins, T. G., \& Wilson, J. G. (2005). Impact of the River Liffey Discharge on Nutrient and Chlorophyll Concentration in the Liffey Estuary and Dublin Bay (Irish Sea). Estuarine Coastal and Shelf Science, 64, 323-334. 
O’Higgins, T. G., Cooper, P., Roth, E., Newton, A., Farmer, A., Goulding, I., \& Tett, P. (2014). Temporal Constraints on Ecosystem Management: Definitions and Examples from Europe's Regional Seas. Ecology and Society, 19(3): 12 pages.

Olesen, E., Kleeivn, A. R., Skjoldal, H. R., \& von Quillfeldt, C. H. (2011). PlaceBased Management at Different Spatial Scales. Journal of Coastal Conservation, 15, 257-269.

OSPAR. (2008). Eutrophication Status of the OSPAR Maritime Area-Second OSPAR Integrated Report. ISBN 978-1-906840-13-6.

Ostrom, E. (2003). How Types of Goods and Property Rights Jointly Affect Collective Action. Journal of Theoretical Politics, 15, 239-270.

Ostrom, E. (2009). A General Framework for Analysing Sustainability of SocialEcological Systems. Science, 325, 419-422.

Pendleton, L., et al. (2007). Is the Non-market Literature Adequate to Support Coastal and Marine Management? Ocean and Coastal Management, 50, 363-378.

Potts, T., Alexander, K., \& O’Higgins, T. (2013). Supporting Marine Spatial Planning with Local Socioeconomic Data (p. 21). Scotland Centre for Expertise in Water.

Potts, T., Pita, C., O’Higgins, T., \& Mee, L. D. (2016). Who Cares? European Attitudes Towards Marine and Coastal Environments. Marine Policy, 72, 59-66.

Risø National Laboratory. (2004). Offshore Wind Energy and Industrial Development in the Republic of Ireland. Dublin: Sustainable Energy Ireland.

Scottish Government. Marine (Scotland) Act (2010). Retrieved from http://www. legislation.gov.uk/asp/2010/5/pdfs/asp_20100005_en.pdf.

Simpson, J. H. (1976). A Boundary Front in the Summer Regime of the Celtic Sea. Estuarine Coastal and Shelf Science, 4(1), 71-81.

Simpson, J., \& Hunter, J. (1974). Fronts in Irish Sea. Nature, 250(5465), 404.

Stelzenmüller, V., Coll, M., Mazaris, A. D., Giakuomi, S., Katsanevakis, S., Portman, M. E., Degen, R., Mackelworth, P., Gimple, A., Albano, P. G., Almpanidou, V., Claudet, J., Essl, F., Evagelopoulos, T., Heymans, J. J., Genov, T., Kark, S., Micheli, F., Pennino, M. G., Rilov, G., Rumes, B., Steenbeek, J., \& Ojaveer, H. (2018). A Risk-Based Approach to Cumulative Effect Assessments for Marine Management. Science of the Total Environment, 612, 1132-1140.

Tallis, H., Levin, P. S., Ruckelshaus, M., Lester, S. E., McLeod, K. L., Fluharty, D. L., \& Halpern, B. S. (2010). The Many Faces of Ecosystem-Based Management: Making the Process Work Today in Real Places. Marine Policy, 34, 340-348.

Van Tatenhove, J., Raakjaer, J., van Leeuwen, J., \& van Hoof, L. (2014). Regional Cooperation for European Seas: Governance Models in Support of the Implementation of the MSFD. Marine Policy, 50, 364-372. https://doi. org/10.1016/j.marpol.2014.02.020.

Vega, A., \& Hynes, S. (2017). Ireland's Ocean Economy. Socio-Economic Marine Research Unit, NUI, Galway. Pp 67 ISSN 2009-6933. 
Open Access This chapter is licensed under the terms of the Creative Commons Attribution 4.0 International License (http://creativecommons.org/licenses/by/4.0/), which permits use, sharing, adaptation, distribution and reproduction in any medium or format, as long as you give appropriate credit to the original author(s) and the source, provide a link to the Creative Commons licence and indicate if changes were made.

The images or other third party material in this chapter are included in the chapter's Creative Commons licence, unless indicated otherwise in a credit line to the material. If material is not included in the chapter's Creative Commons licence and your intended use is not permitted by statutory regulation or exceeds the permitted use, you will need to obtain permission directly from the copyright holder. 